\title{
Memanfaatkan Barang Bekas Untuk Membangun Kreativitas Dalam Masa Adaptasi Baru Selama Pandemi Covid-19
}

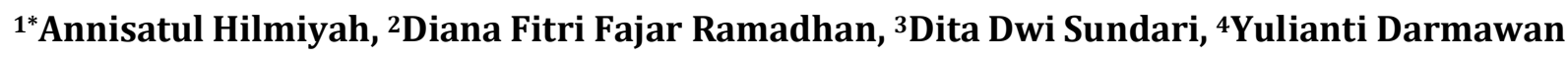 \\ Universitas Pamulang, Tangerang Selatan, Banten, Indonesia \\ *anisatulhil91@gmail.com
}

\begin{abstract}
Abstrak
Adaptasi kebiasaan baru merupakan hal yang penting untuk dilakukan agar cepat terbiasa dengan cara hidup yang baru dalam menjalankan aktivitas ditengah pandemi. Dengan semakin cepat orangorang beradaptasi maka dengan cepat pula menyongsong aktivitas yang lebih produktif disituasi saat ini. Karena adaptasi kebiasaan baru diperlukan untuk tetap produktif saat berdampingan dengan COVID-19. Maka dari itu dilaksanakannya kegitaan PKM yaitu suatu bentuk pengabdian masyarakat untuk mengedukasi masyarakat terkait bagaimana memanfaatkan waktu luang di masa New Normal agar lebih produktif. Dalam pengabdian ini metode pelaksanaan yang digunakan adalah dengan edukasi dan praktek pembuatan prakarya dengan memanfaatkan barang bekas yang dapat dijumpai di rumah. Pengabdian masyarakat ini dilaksanakan di TPA/TPQ Al-Falah, Pondok Benda, Pamulang, Tangerang Selatan.
\end{abstract}

Kata Kunci: Memanfaatkan Barang Bekas, New Normal, Adaptasi Kebiasaan Baru, TPA/TPQ Al Falah

\begin{abstract}
The adaptation of new habits is an important thing to do so that can quickly get used to the new way of life in carrying out activities amid a pandemic. The faster people adapt, the faster they support more productive activities in the current situation. Because the adaptation of new habits is needed to stay productive while side by side with COVID-19. Therefore, the implementation of PKM activities is a form of community service to educate the public regarding how to use free time during the New Normal to be more productive. In this service, the implementation method used is education and the practice of making crafts by utilizing used goods that can be found at home. This community service is carried out in TPA/TPQ Al-Falah, Pondok Benda, Pamulang, Tangerang Selatan.
\end{abstract}

Keywords: Use Secondhand Goods, New Normal, New Habit Adaptation, TPA/TPQ AI-Falah

\section{PENDAHULUAN}

Tahun 2020 Indonesia bahkan dunia digemparkan dengan kemunculan virus jenis baru yang disebut sebagai Virus Corona atau sebutan ilmiahnya adalah COVID-19. Dan Organisasi Kesehatan Dunia (WHO) telah menyatakan Penyakit Virus Corona 2019 (COVID-19) sebagai pandemi. Kasus COVID- 19 juga semakin meluas di berbagai wilayah Indonesia, terlihat dari semakin banyaknya kasus dan angka kematian akibat COVID-19. Dampak COVID-19 di Indonesia terasa pada semua aspek yaitu politik, ekonomi, sosial, budaya, pertahanan dan keamanan, serta kesejahteraan masyarakat di Indonesia. Maka dari itu dalam Pragholapati (2020) mengatakan Pemerintah Indonesia menetapkan Corona Virus Disease 2019 (COVID-19). Hal ini menciptakan keadaan darurat kesehatan masyarakat di Indonesia yang harus dilaksanakan sesuai dengan ketentuan peraturan perundang-undangan. Pemerintah Indonesia dalam memerangi COVID-19 dilakukan dengan berbagai cara yang tertuang dalam peraturan pemerintah. Sesuai dengan Peraturan Pemerintah Nomor 21 Tahun 2020 tentang Pembatasan Sosial Berskala Besar (PSBB) dalam rangka percepatan penanganan COVID-19. Dan pembatasan dalam jangka panjang akan mengakibatkan penurunan produktivitas masyarakat yang berimbas pada perekonomian masyarakat. Maka dari itu Pemerintah Indonesia melakukan upaya melalui membangun kebiasaan baru agar masyarakat dapat beradaptasi melalui perubahan gaya hidup ditengah situasi COVID-19 dan disebut dengan New Normal.

New Normal adalah suatu cara hidup baru atau cara baru dalam menjalankan aktivitas hidup ditengah pandemi COVID-19 yang belum selesai (Mada Sigit Pamungkas dalam Habibi 
Andrian, 2020). Dimana New Normal sebagai alternatif dasar kebijakan nasional untuk memenuhi kebutuhan masyarakat terkait produktivitas kerja dan interaksi sosial sekarang. Andrian (2020) menjelaskan bahwa New Normal atau contoh bentuk kebiasan baru yang muncul ditengah situasi sekarang ini antara lain enggan bersalaman atau berjabat tangan. Muncul kebiasaan baru dalam Corona yang menggunakan siku sebagai pengganti telapak tangan. Contoh lain kebiasaan memakai masker, himbauan, anjuran, bahkan perintah memakai masker di luar rumah sudah menjadi kebiasaan baru. Begitu juga kebiasaan mencuci tangan dan jaga jarak. Intinya bahwa New Normal berhubungan dengan perilaku dan kebiasaan baru individu dan/atau masyarakat global saat masa pandemi COVID-19.

Untuk menyonsong aktivitas produktif disituasi pandemi COVID-19 saat ini diperlukannya adaptasi pada kebiasaan baru. Dan untuk mempermudah masyarakat untuk lebih mengenal apa itu kebiasaan baru di New Normal ini maka digunakannya media edukasi New Normal. Media edukasi dapat memperlihatkan informasi rumit dengan singkat dan jelas, serta selain mempermudah masyarakat untuk mengerti, tentunya juga menarik perhatian dengan visualisasi gambar yang ditunjukkan. Disamping itu tanpa kita sadari masih banyak waktu luang di masa pandemi dalam ajakan pemerintah untuk "Di rumah Aja" yang tidak digunakan secara efektif, serta digunakan untuk kegiatan yang membuang waktu.

Maka dari itu dilakukannya PKKM, yaitu pengabdian masyarakat untuk memberikan informasi mengenai pemanfaatan waktu luang agar lebih produktif, dan dimana dilakukannya pengabdian masyarakat pada TPA/TPQ Al-Falah, Pondok Benda, Pamulang, Tangerang Selatan untuk membantu meningkatkan kreativitas serta produktivitas dengan harapan dapat terlihat perubahan peningkatan yang lebih baik terkait dengan kebiasaan baru dan peraturan yang harus dilaksanakan untuk menyonsong aktivitas yang lebih produktif.

\section{METODE PELAKSANAAN}

Kegiatan pengabdian masyarakat tentang mengedukasi bagaimana membangun kreativitas demi kegiatan yang lebih produktif bagi masyarakat TPA/TPQ Al-Falah, Pondok Benda, Pamulang, Tangerang Selatan. Kegiatan pengabdian masyarakat tentang membangun kreativitas dan produktivitas di masa adaptasi baru dilakukan dengan cara edukasi dan sosialisasi. Untuk edukasi dan sosialisasi dilakukan secara langsung di lokasi yaitu TPA/TPQ Al-Falah, Pondok Benda, Pamulang, Tangerang Selatan dengan menjalankan prokes yang ditetapkan oleh pemerintah.

Faktor pendukung dan penghambat kegiatan pengapdian masyarakat edukasi adaptasi kebiasaan baru sebagai berikut:

1. Faktor pendukung

a. Tersedia tempat untuk melaksanakan kegiatan PPKM

b. Antusiasme masyarakat untuk mengetahui cara pelaksanan adaptasi kebiasaan baru.

c. Dukungan dari pembina TPA/TPQ Al-Falah, Pondok Benda, Pamulang, Tangerang Selatan

2. Faktor penghambat adalah Keterbatasan waktu

\section{HASIL DAN PEMBAHASAN}

Pada masa adaptasi kebiasaan baru atau yang biasa dikenal oleh masyarakat dengan istilah New Normal, masyarakat terdampak pandemi COVID-19 sudah mulai diperbolehkan untuk melakukan kegiatan diluar rumah dengan tetap memperhatikan protokol kesehatan yang direkomendasikan oleh World Health Organization dan Kementrian Kesehatan Rebuplik Indonesia. Namun masih banyak juga kegiatan yang kita lakukan di rumah mengingat hanya sebagian orang yang diperbolehkan untuk melakukan kegiatan di luar rumah sesuai anjuran pemerintah. Kegiatan yang bertemakan membangun kreativitas dengan memanfaatkan barang bekas untuk meningkatkan produktivitas di masa adaptasi baru . Beberapa hasil dokumentasi terkait edukasi di TPA/TPQ Al-Falah, Pondok Benda, Pamulang, Tangerang Selatan diantaranya adalah sebagai berikut:

1. Edukasi mengenai masa adaptasi kebiasaan baru di TPA/TPQ Al-Falah, Pondok Benda, Pamulang, Tangerang Selatan 


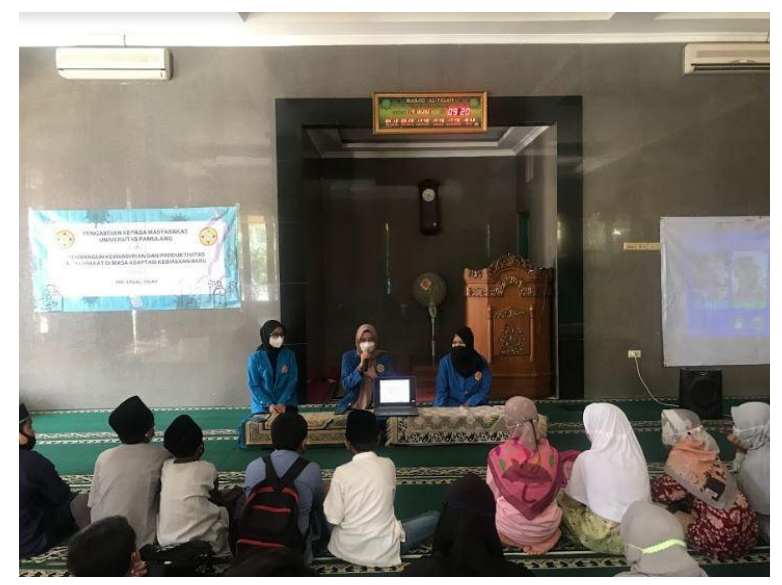

Gambar 1. Edukasi mengenai masa adaptasi kebiasaan baru

2. Edukasi bagaimana membangun kreativitas dengan memanfaatkan barang bekas di masa adaptasi kebiasaan baru di TPA/TPQ Al-Falah, Pondok Benda, Pamulang, Tangerang Selatan

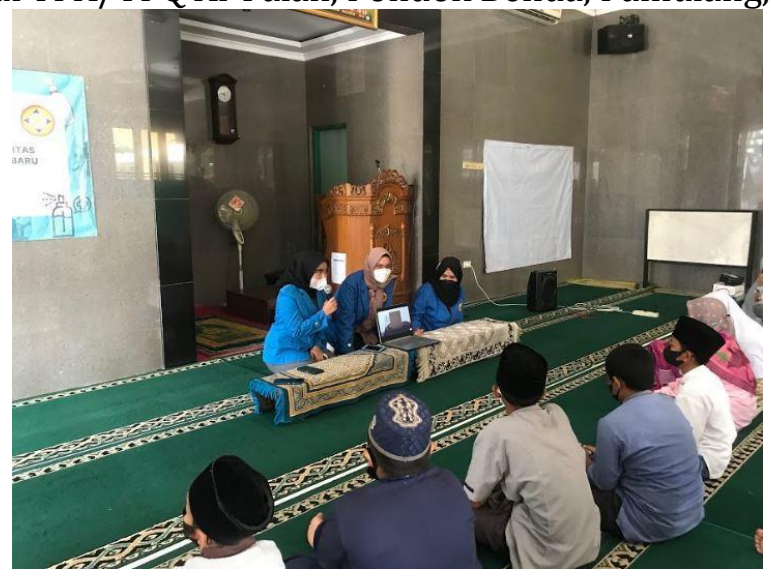

Gambar 2. Edukasi membangun kreativitas

3. Praktik pembuatan prakarya di TPA/TPQ Al-Falah, Pondok Benda, Pamulang, Tangerang Selatan

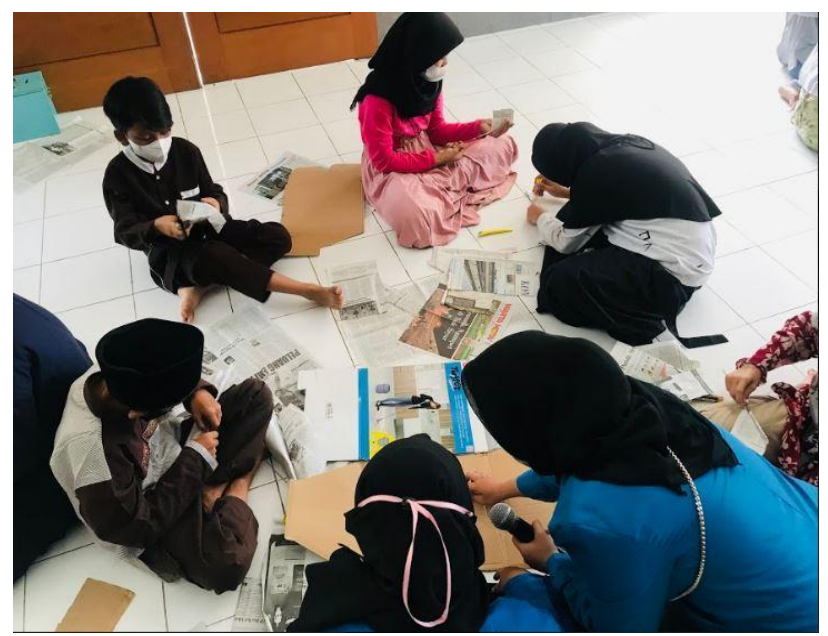

Gambar 3. Pembuatan Prakarya

\section{KESIMPULAN}

Kesimpulan dalam adaptasi kebiasaan baru atau yang biasa dikenal oleh masyarakat dengan istilah New Normal dalam dampak COVID-19 ini adalah adanya perubahan yang terjadi dalam kebiasaan tatanan hidup masyarakat. Disamping itu tanpa kita sadari masih banyak waktu luang di masa pandemi dalam ajakan pemerintah untuk "Di rumah Aja" yang tidak digunakan 
secara efektif, serta digunakan untuk kegiatan yang membuang waktu. Perubahan yang dimaksud adalah diterapkannya protocol kesehatan dan berbagai aturan pada kegiatan yang dilakukan masyarakat, yang bertujuan untuk mengurangi dan mencegah penyebaran COVID-19 serta menjadikan waktu luang yang ada menjadi lebih produktif dengan memanfaatkan barang bekas yang dapat kita jumpai di rumah.

\section{DAFTAR PUSTAKA}

Faishol, R., Meliantina, M., Ramiati, E., \& Putri, E. I. E. (2021). Pendampingan Kegiatan Pembelajaran Siswa Dengan Memanfaatkan Barang Bekas Untuk Meningkatkan Minat Dan Kreativitas Belajar Pada Masa Pandemi Covid-19. Abdi Kami: Jurnal Pengabdian Kepada Masyarakat, 4(1), 092-100.

Haryadi, R. N., Rojali, A., \& Fauzan, M. (2021). Sosialisasi Penggunaan Online Shop Berbasis Website Di Umkm Cimanggis. Jurnal Pengabdian Masyarakat Madani (Jpmm), 1(1), 10-16.

Jannah, N. R., \& Pratiwi, W. (2021). Pendampingan Kegiatan Belajar Siswa Dengan Memanfaatkan Barang Bekas Untuk Meningkatkan Minat Dan Kreativitas Belajar Siswa Pada Era Covid-19. Bulletin Of Community Engagement, 1(2), 61-70.

Putri, R. F., \& Silalahi, A. D. (2018, April). Pemanfaatan Limbah Botol Plastik Bekas Menjadi Barang Yang Bernilai Estetika Dan Ekonomi. In Prosiding Seminar Nasional Hasil Pengabdian (Vol. 1, No. 1, Pp. 233-236).

Setyoko, A. (2012). Barang Bekas Sebagai Bahan Berkarya Seni Kriya Di Komunitas Tuk Salatiga: Proses Dan Nilai Estetis. Arty: Jurnal Seni Rupa, 1(1).

Sunarsi, D., Et Al. (2021). Penyuluhan Wirausaha Untuk Meningkatkan Ekonomi Keluarga Dengan Daur Ulang Barang Bekas Desa Mekarsari Kabupaten Bogor. Jurnal Padma: Pengabdian Dharma Masyarakat, 1(2). 